\title{
Durability studies on ready mix concrete using mineral admixtures and manufactured sand
}

DOI : 10.36909/jer.ICCEMME.15755

\author{
Jagadish Vengala ${ }^{1 *}, \mathrm{~K}$ Ramesh $^{1}$, Manjunath $\mathrm{M}^{2}$, Manish S Dharek ${ }^{3}$, K Krishna Mohan ${ }^{1}$ \\ ${ }^{1}$ Department of Civil Engineering, Prasad V Potluri Siddhartha Institute of Technology, \\ Vijayawada, Andhra Pradesh, India. \\ ${ }^{2}$ Department of Civil Engineering, GITAM University, Bangalore, Karnataka, India. \\ ${ }^{3}$ Department of Civil Engineering, BMS College of Engineering, Bangalore, India. \\ *Corresponding Author Email: jdvengala@ pvpsiddhartha.ac.in
}

\begin{abstract}
To meet the intensifying demand of fine aggregate in construction sector, manufactured sand has become a viable alternative to the river sand. Ready mix concrete (RMC) is playing vital role in fast-track construction particularly in Tire-II cities in India. The strength and durability concerns about using 100\% manufactured sand along with mineral admixtures in RMC plant needs to be addressed through suitable experimental demonstrations. This research gives the experimental results on strength and durability studies of concrete carried out on samples obtained from RMC Plant by making use of manufactured sand containing (50\% of crushed sand and $50 \%$ of the crushed rock fines) as replacement for natural sand. Trials on partial replacing cement with fly ash content of $33 \%$ and GGBS of $40 \%$ has also been carried out. Compressive and split-tensile strength studies were conducted on cubes (150mmx 150mmx 150mm) and cylinders $(150 \mathrm{~mm} \times 300 \mathrm{~mm})$ at $7,14 \& 28$ days of curing. NonDestructive tests such as Ultra Sonic Pulse Velocity (UPV) and rebound hammer tests were conducted to assess the quality of these mixes. Durability tests were conducted and comparison of the $\%$ of loss in mass and \% of loss in strength for concrete samples subjected to acid attack, sulphate attack, alkaline attack tests were also carried out. Rapid chloride permeability test (RCPT) was conducted to check the concrete resistance against chloride ions penetration. The experimental results revealed that the use of $100 \%$ manufactured sand along with mineral admixtures in producing ready mix concrete is a good choice in view of the non-availability of river sand to meet the demands of fast-track construction projects.
\end{abstract}

Key words: Ready mixed concrete, GGBS, Fly ash, RCPT Test, Sulphate attack, acid attack.

\section{INTRODUCTION}

Fine aggregate or Sand which is one of the key ingredients in concrete, occupies about $35 \%$ of the total volume in concrete (Anandan et al., 2019). This material is mainly obtained 
through excavation from the river bed and hence contains components such as sulphates, silt, clay and inorganic material which has a detrimental effect on the durability and long term performance (Saluja et al., 2019). This sand mining from river beds is known to affect the ground water levels in addition to erosion (Ahmad et al., 2019). Since, river sand is not available easily and abundantly, the cost of river sand has gone significantly off-late (Ali et al., 2021). Due to these issues, alternatives such as rock sand /manufactures sand has become a popular choice in place of river sand for most of the activities such as concreting, masonry and plastering work in most of the building/infrastructure projects in the urban regions (Xin et al., 2020). Rock sand is a factory-made material obtained through crushing of larger stones obtained from quarries to the required size (Lim et al., 2019). This material has become a viable substitute for natural river sand as it satisfies the various environmental, technical and commercial requirements. Suitable quality control while using rock sand/manufacture sand can lead to better performance in fresh state and long-term performance (durability) (Tangadagi et al., 2020). Ready mixed concrete (RMC) is playing vital role in fast-track construction particularly in Tire-II cities of India. River sand in Indian context is not graded properly in many parts of the country and generally contains disproportionate silt and organic impurities, which can be unfavorable to the durability of steel in concrete, whereas manufactured sand contains no organic impurities or silt. In the recent year's construction has taken a step forward with the replacement of cement with mineral admixtures like silica fume, GGBS, rice husk ash etc (Güçlüer, 2021; M et al., 2021; Alnahhal et al., 2018; Tangadagi et al., 2021). Durability is one of the major factors which is neglected quite often (Manjunatha et al., 2021; Muthusamy et al., 2020). Durability studies have to be performed in order to determine the resistance of concrete due to chemical attack and weathering actions, while maintaining the desired engineering properties (Thangapandi et al., 2020). In this experimentation, an effort has been made to find some of the durability parameters for ready mix concrete using $100 \%$ manufactured sand and partially replacing cement with GGBS and fly ash (Qureshi et al., 2020).

\section{MATERIALS AND MIX DETAILS}

53 grade of Ordinary Portland Cement (OPC) was used in this study and confirms to IS:122692013 (IS:12269-2013, 2013). Fly ash is sourced from nearby thermal power station, Vijayawada, Andhra Pradesh and meeting the requirements of IS:3812-1981. Similarly, Ground granulated blast-furnace slag (GGBS) was collected from Vizag steel Plant, Vizag. In the concrete mixes, locally available dry coarse aggregate meeting IS: 383 specifications were used (IS:383-1970, 1970). The void between the coarse aggregates is filled with fine aggregate 
(FA) and hydrated cement paste. The specific gravity of the fine aggregate (manufactured sand) used in the investigation was 2.65 and the fine aggregate used in this present investigation comes under Zone- III. Manufactured sand used as a FA in this study contains $50 \%$ of crushed sand and $50 \%$ of crushed rock fines. OPC is part replaced with fly-ash content of $33 \%$ for one mix and part replaced with GGBS of $40 \%$ for another mix. M25 grade of concrete was designed and optimum mix was taken for conducting trials at RMC Plant. Table 1 gives the mix details of the trails conducted at RMC Plant.

Table 1. Mix details of the ready mixed concrete samples collected from the plant $\left(\mathrm{kg} / \mathrm{m}^{3}\right)$.

\begin{tabular}{|c|c|c|c|c|c|c|c|c|}
\hline Mix & \multirow{2}{*}{$\begin{array}{c}\text { Cement } \\
\text { Designation }\end{array}$} & \multirow{2}{*}{$\begin{array}{c}\text { Fly } \\
\text { Ash }\end{array}$} & \multirow{2}{*}{ GGBS } & \multicolumn{2}{|c|}{ Coarse aggregate } & \multicolumn{2}{|c|}{ Fine Aggregate } & \multirow{2}{*}{ Water } \\
\cline { 5 - 8 } & & & $\mathbf{2 0 m m}$ & $\mathbf{1 0 m m}$ & Crushed sand & CRF & \\
\hline M-I & 330 & -- & -- & 711 & 474 & 165 & 392 & 165 \\
\hline M-II & 230 & 100 & -- & 785 & 400 & 150 & 379 & 150 \\
\hline M-III & 200 & -- & 130 & 855 & 400 & 160 & 417 & 165 \\
\hline
\end{tabular}

\section{METHODOLOGY ADOPTED}

This section deals with the methodology adopted for this investigation. Based on the mix proportions shown in Table -1 , samples comprising of cubes and cylinders cast at the Readymix concrete plant were collected and brought to the lab and cured for varying curing durations (7,14,28 days). This was done to study the gain of strength for varying curing durations. The tests conducted on these specimens comprised of destructive and non-destructive in nature. Under non-destructive, UPV and rebound hammer tests were conducted. The destructive test comprised of compressive and split tensile strength. The performance of the concrete under varying environments was also studied through durability studies. This comprised of observing the $\%$ loss in mass of specimens and \% loss in compressive strength under acidic and alkaline conditions. The specimens were dipped in $\mathrm{HCl}$ to simulate the acidic condition. The specimens were dipped in sodium hydroxide solution to simulate the alkaline condition. Similarly, the specimens were dipped in sodium sulphate solution to simulate the sulphate environment. The resistance of the concrete against penetration of chloride was also studied through the RCPT test. Figure 1 shows the flowchart with respect to the methodology adopted. 


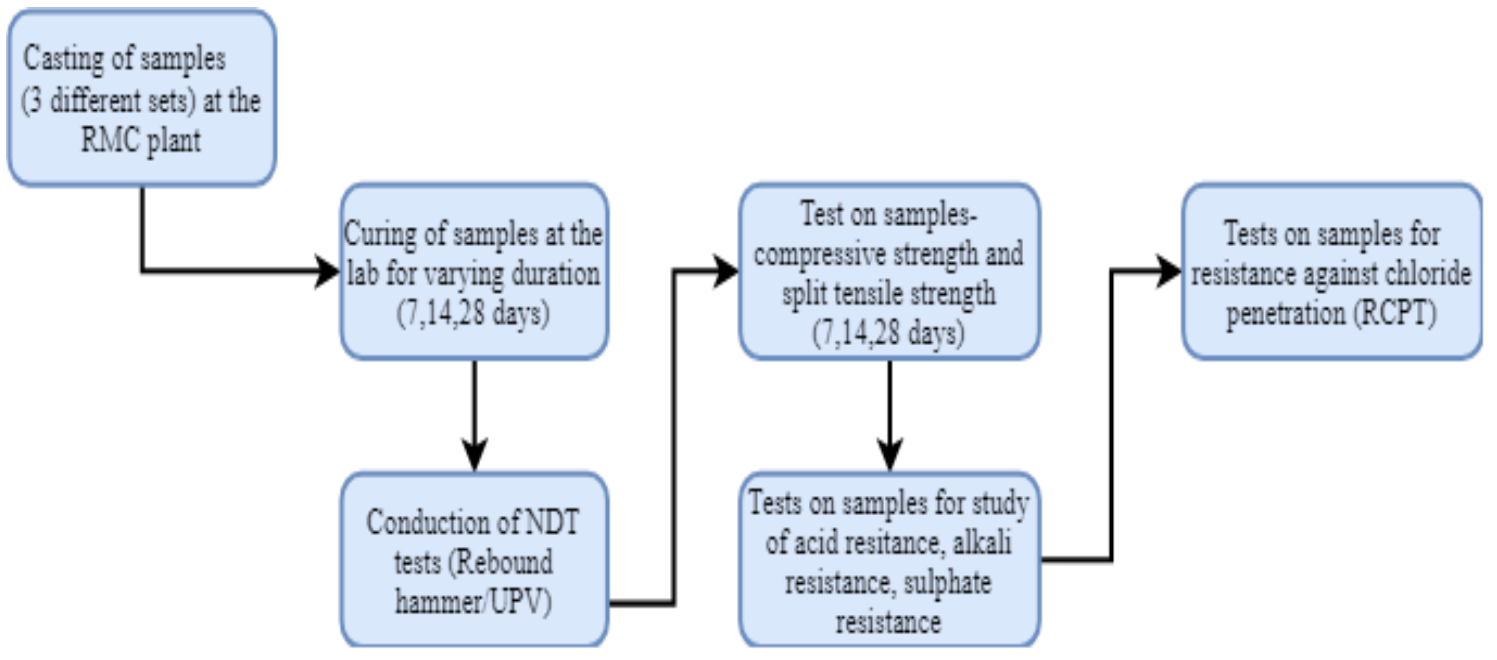

Figure 1. Flowchart showing the methodology for the present study

\section{COMPRESSIVE AND SPLIT TENSILE TESTS}

To conduct the compressive strength test concrete cubes of $15 \mathrm{~cm}$ x $15 \mathrm{~cm} \times 15 \mathrm{~cm}$ were cast for 7, 14, 28 days. Similarly, cylindrical specimens of $15 \mathrm{~cm}$ x $30 \mathrm{~cm}$ size were cast to check the split tensile strength. For all the three mixes specimens were cast at RMC Plant. The specimens were then collected from RMC Plant and brought back to the laboratory after the initial curing. The specimens were water cured till before the testing. The compressive and split tensile tests were conducted. Table 2 gives the results of compressive and split tensile strength results of concrete mixes at each curing period.

Table 2. Compressive and split tensile strength results of test specimens at 7, 14 and 28 days of curing

\begin{tabular}{|c|c|c|c|c|c|c|}
\hline \multirow{2}{*}{$\begin{array}{c}\text { Mix } \\
\text { designation }\end{array}$} & \multicolumn{3}{|c|}{ Compressive strength in MPa } & \multicolumn{3}{c|}{ Split tensile strength in MPa } \\
\cline { 2 - 7 } & $\mathbf{7}$ & $\mathbf{1 4}$ & $\mathbf{2 8}$ & $\mathbf{7}$ & $\mathbf{1 4}$ & $\mathbf{2 8}$ \\
\hline M-I & 23.1 & 38.7 & 42.5 & 2.43 & 2.76 & 2.94 \\
\hline M-II & 16.4 & 37.8 & 41.2 & 1.79 & 2.23 & 2.59 \\
\hline M-II & 18.1 & 38.9 & 44.9 & 1.55 & 2.44 & 2.78 \\
\hline
\end{tabular}




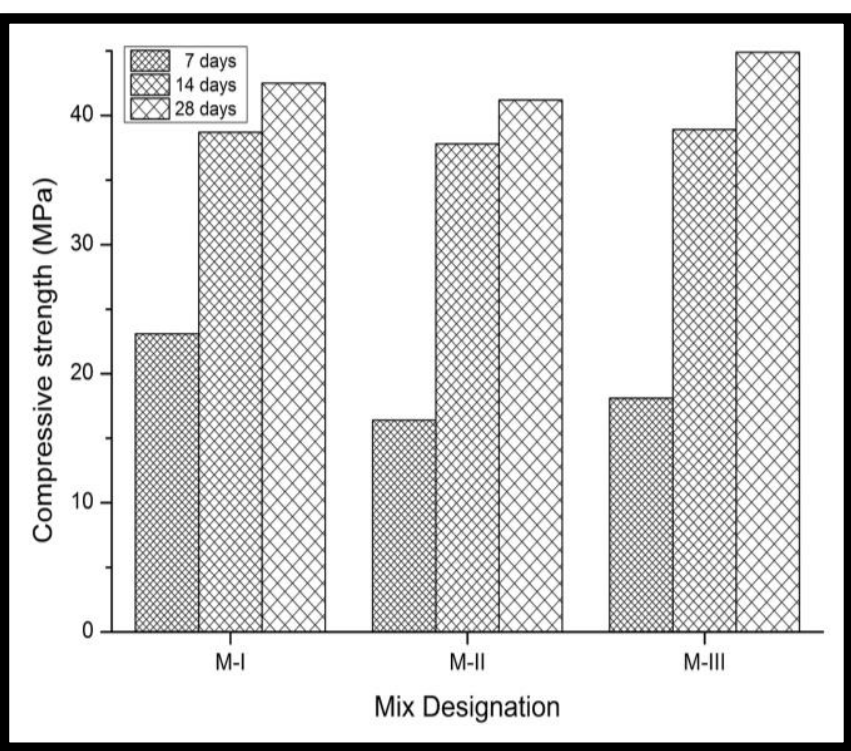

Figure 2. Compressive strength test for all the mixes.

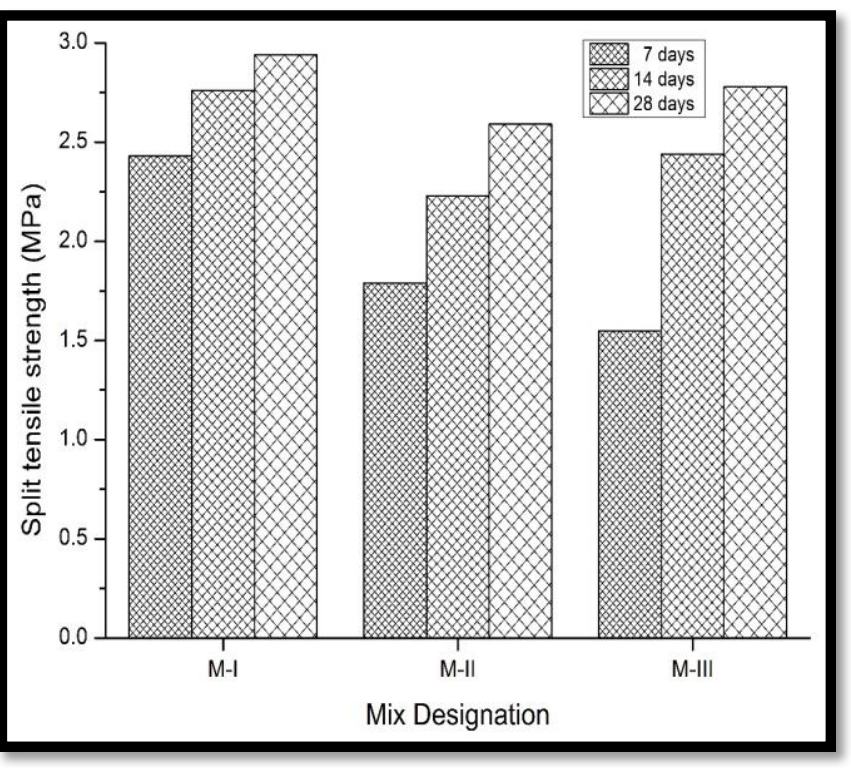

Figure 3. Split tensile strength test for all the mixes .

From Figures 2 and 3, it can be seen that all the mixes satisfy the strength requirements of M25 grade. Mix M-II with fly ash is slightly lower strength when compared with the other two mixes. Based on the results it clearly indicates that the part replacement of cement with GGBS or fly ash does not alter the required strength using $100 \%$ of manufactured sand in place of river sand.

\section{NON-DESTRUCTIVE TESTS: REBOUND HAMMER TEST (RHT)}

The RHT was performed on all three mix specimens to determine the consistency of the concrete and the possible compressive strength of concrete using appropriate correlations between rebound index and compressive strength. It gives the surface quality of the concrete. The rebound test was carried out on the cube specimens before the conduction of destructive test. Table 3 gives the rebound hammer values of cube specimens conducted at different ages. Similarly, Figure 4 highlights the rebound hammer test results of concrete mixes. 
Table 3. Rebound Hammer values of Cube specimens at 7, 14 and 28 days of curing

\begin{tabular}{|c|c|c|c|c|c|c|c|}
\hline \multirow{2}{*}{$\begin{array}{c}\text { Mix } \\
\text { designation }\end{array}$} & \multirow{3}{*}{$\begin{array}{c}\text { Age of Specimen in } \\
\text { days }\end{array}$} & \multicolumn{6}{|c|}{ Rebound Hammer Value } \\
\cline { 1 - 7 } & & $\mathbf{1}$ & $\mathbf{2}$ & $\mathbf{3}$ & $\mathbf{4}$ & $\mathbf{5}$ & Avg. \\
\hline M-I & \multirow{3}{*}{7} & 10 & 12 & 13 & 14 & 12 & 12.2 \\
\hline M-II & & 13 & 12 & 12 & 13 & 10 & 12.0 \\
\hline M-III & & 12 & 14 & 12 & 14 & 10 & 12.4 \\
\hline M-I & \multirow{4}{*}{14} & 12 & 16 & 16 & 18 & 15 & 15.4 \\
\hline M-II & & 14 & 16 & 16 & 16 & 14 & 15.2 \\
\hline M-III & & 16 & 18 & 18 & 14 & 16 & 16.4 \\
\hline M-I & \multirow{2}{*}{28} & 26 & 21 & 24 & 26 & 20 & 23.4 \\
\hline M-II & & 24 & 25 & 24 & 22 & 21 & 23.2 \\
\hline M-III & & 26 & 25 & 21 & 22 & 25 & 23.6 \\
\hline
\end{tabular}

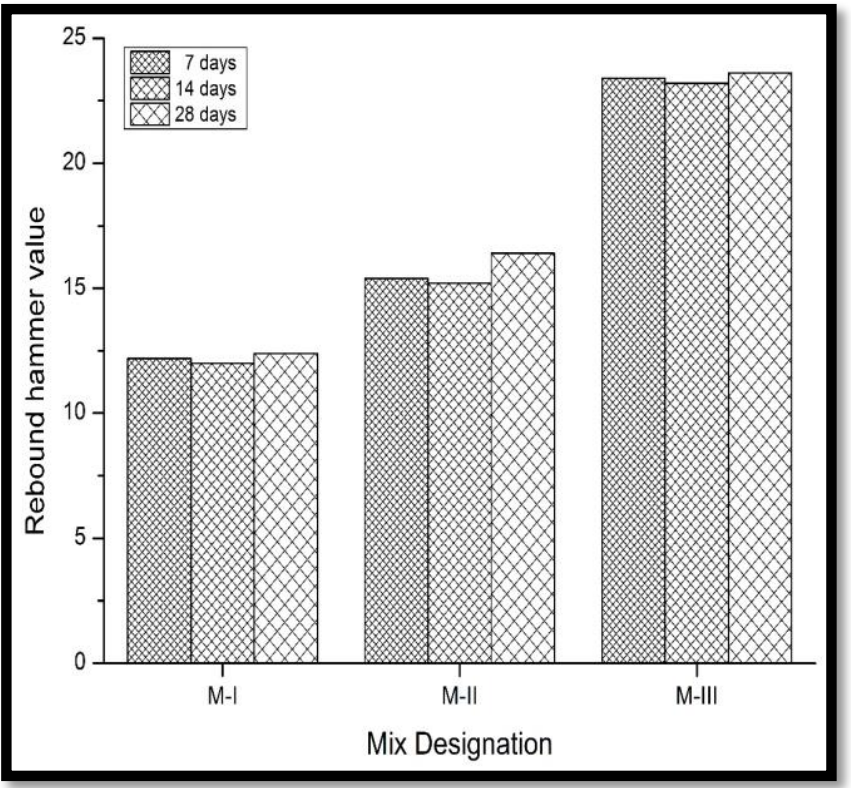

Figure 4. Rebound hammer test results

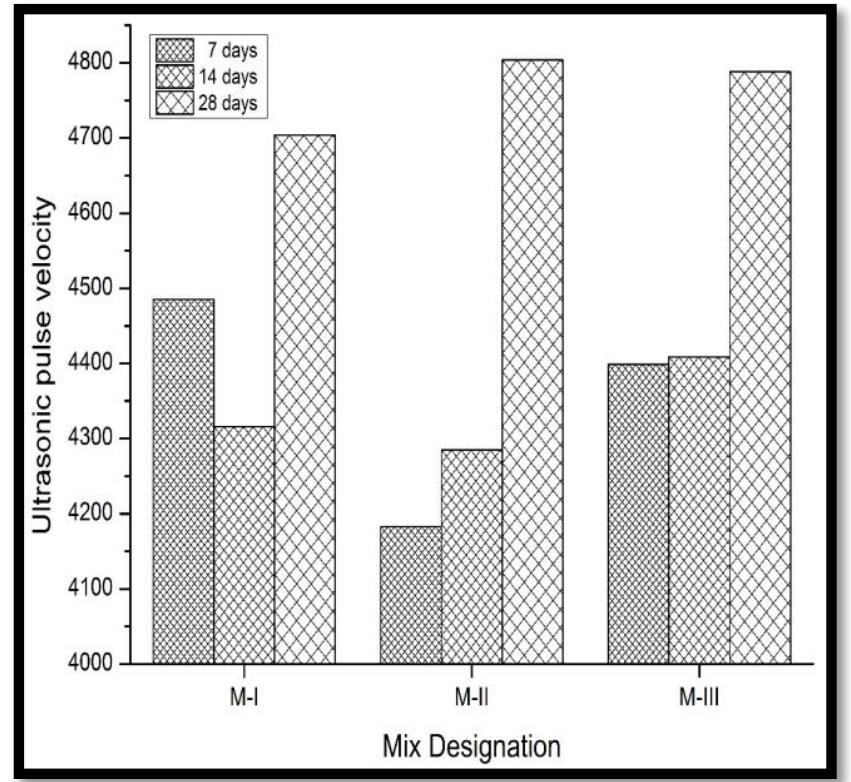

Figure 5. UPV test results

\section{UPV TEST}

Table 4. UPV values of Cube specimens for 7, 14 and 28 days 


\begin{tabular}{|c|c|c|c|c|c|c|c|}
\hline \multirow{2}{*}{ Mix details } & \multirow{2}{*}{$\begin{array}{c}\text { Specimen age } \\
\text { in days }\end{array}$} & \multicolumn{6}{|c|}{$\begin{array}{l}\text { UPV values in } \mathrm{m} / \mathrm{s} \text { for cylinder specimens } \\
(300 \mathrm{mmx} 150 \mathrm{~mm})\end{array}$} \\
\hline & & 1 & 2 & 3 & 4 & Avg. & $\begin{array}{c}\text { Concrete } \\
\text { Quality }\end{array}$ \\
\hline M-I & \multirow{3}{*}{7} & 4337 & 4545 & 4642 & 4414 & 4485 & Good \\
\hline M-II & & 4046 & 4015 & 4526 & 4144 & 4183 & Good \\
\hline M-III & & 4685 & 3978 & 4514 & 4422 & 4399 & Good \\
\hline M-I & \multirow{3}{*}{14} & 4045 & 4246 & 4527 & 4444 & 4316 & Good \\
\hline M-II & & 4253 & 4343 & 4415 & 4127 & 4285 & Good \\
\hline M-III & & 4585 & 4078 & 4514 & 4322 & 4409 & Good \\
\hline M-I & \multirow{3}{*}{28} & 4277 & 4808 & 4954 & 4777 & 4704 & Excellent \\
\hline M-II & & 4776 & 4762 & 4869 & 4818 & 4804 & Excellent \\
\hline M-III & & 4893 & 4648 & 4772 & 4884 & 4788 & Excellent \\
\hline
\end{tabular}

The ultrasonic pulse velocity approach may be used to ascertain the homogeneity of the concrete as well as to evaluate its consistency in relation to the standard requirements. UPV test was conducted on both cube specimens and cylindrical specimens. The results of the UPV values of cube specimens at 7, 14, 28 days are as shown in Table 4. Likewise, Figure 5, showcases the UPV test results of concrete mixes at each curing period. Based on the Non-destructive tests conducted (rebound hammer and UPV tests) on all the three concrete mixes the quality of concrete obtained is good for all the mixes.

\section{DURABLITY TESTS}

\section{ACID ATTACK, ALKALINE ATTACK and SULPHATE ATTACK TESTS:}

The acid resistance behavior of concrete was examined by submerging the cube specimens in Hydrochloric acid with $\mathrm{pH}=2$ at $5 \%$ mass of water. Similarly, the alkali resistance of concrete was investigated by immersing the cube specimens in $5 \%$ of Sodium hydroxide alkaline water. The sulphate resistance of concrete was investigated by immersing the cube specimens in 5\% Sodium sulphate solution by mass of water. In each case, $\%$ loss in mass of specimens and \% compressive strength loss was noted down. The resistance of concrete to sulphate attack was investigated by comparing the loss of compressive strength of concrete cubes immersed in sulphate water containing $5 \%$ of sodium sulphate $\left(\mathrm{MnSO}_{4}\right)$ by mass and those which are cured in normal water. Casted cubes were cured in water for 14 days, dried for one day, and then submerged in solution-added water for 14 days. Throughout the experiment, the concentration of the solution remained unchanged. The concrete cubes were removed from the solution water after 14 days and tested for compressive strength according to IS: 516 . In each case, \% loss in mass of specimens and \% loss in compressive strength was noted down. Table 5, 6 and 7 gives 
the $\%$ mass loss of specimen and \% compressive strength loss of the specimen after acid, alkaline and sulphate attack test.

Table 5. \% mass loss of specimens and \% strength loss after acid attack test

\begin{tabular}{|c|c|c|c|c|c|c|}
\hline \multirow{2}{*}{$\begin{array}{l}\text { Mix } \\
\text { designation }\end{array}$} & \multicolumn{2}{|c|}{$\begin{array}{l}\text { specimens cured in } \\
\text { normal water }\end{array}$} & \multicolumn{2}{|c|}{$\begin{array}{c}\text { Specimens cured in acid } \\
\text { water }\end{array}$} & \multirow{2}{*}{$\begin{array}{c}\% \text { loss } \\
\text { of mass }\end{array}$} & \multirow{2}{*}{$\begin{array}{c}\% \text { loss of } \\
\text { compressive } \\
\text { strength }\end{array}$} \\
\hline & $\begin{array}{c}\text { Mass } \\
(\mathrm{kg})\end{array}$ & $\begin{array}{c}\text { Compressive } \\
\text { strength (MPa) }\end{array}$ & $\begin{array}{c}\text { Mass } \\
(\mathrm{kg}) \\
\end{array}$ & $\begin{array}{c}\text { Compressive } \\
\text { strength (MPa) }\end{array}$ & & \\
\hline M-I & 9.07 & 37.8 & 8.98 & 34.1 & 0.99 & 9.78 \\
\hline M-II & 9.07 & 38.7 & 8.96 & 33.1 & 1.21 & 14.47 \\
\hline M-II & 9.07 & 38.9 & 9.01 & 35.1 & 0.66 & 9.77 \\
\hline
\end{tabular}

Table 6. $\%$ mass loss of specimens and \% strength loss after alkaline attack test

\begin{tabular}{|c|c|c|c|c|c|c|}
\hline \multirow{2}{*}{$\begin{array}{c}\text { Mix } \\
\text { designation }\end{array}$} & \multicolumn{2}{|c|}{$\begin{array}{l}\text { specimens cured in } \\
\text { normal water }\end{array}$} & \multicolumn{2}{|c|}{$\begin{array}{l}\text { specimens cured in } \\
\text { Sulphate water }\end{array}$} & \multirow{2}{*}{$\begin{array}{c}\% \text { loss } \\
\text { of mass }\end{array}$} & \multirow{2}{*}{$\begin{array}{c}\% \text { loss of } \\
\text { compressive } \\
\text { strength }\end{array}$} \\
\hline & $\begin{array}{c}\text { Mass } \\
(\mathbf{k g})\end{array}$ & $\begin{array}{c}\text { Compressive } \\
\text { strength (MPa) }\end{array}$ & $\begin{array}{c}\text { Mass } \\
(\mathbf{k g})\end{array}$ & $\begin{array}{c}\text { Compressive } \\
\text { strength (MPa) }\end{array}$ & & \\
\hline M-I & 9.07 & 37.8 & 8.92 & 32.9 & 1.65 & 12.96 \\
\hline M-II & 9.07 & 38.7 & 8.91 & 32.5 & 1.76 & 16.02 \\
\hline M-II & 9.07 & 38.9 & 8.94 & 34.0 & 1.43 & 12.59 \\
\hline
\end{tabular}

Table 7. \% mass loss of specimens and \% strength loss after sulphate attack test

\begin{tabular}{|c|c|c|c|c|c|c|}
\hline \multirow{2}{*}{$\begin{array}{c}\text { Mix } \\
\text { designation }\end{array}$} & \multicolumn{2}{|c|}{ Water cured specimens } & \multicolumn{2}{|c|}{$\begin{array}{c}\text { Sulphate water cured } \\
\text { specimens }\end{array}$} & \multirow{2}{*}{$\begin{array}{l}\% \text { loss } \\
\text { of mass }\end{array}$} & \multirow{2}{*}{$\begin{array}{c}\% \text { loss of } \\
\text { compressive } \\
\text { strength }\end{array}$} \\
\hline & $\begin{array}{c}\text { Mass } \\
(\mathrm{kg})\end{array}$ & $\begin{array}{c}\text { Compressive } \\
\text { strength (MPa) }\end{array}$ & $\begin{array}{c}\text { Mass } \\
(\mathrm{kg})\end{array}$ & $\begin{array}{c}\text { Compressive } \\
\text { strength (MPa) }\end{array}$ & & \\
\hline M-I & 9.07 & 37.8 & 8.94 & 33.9 & 1.43 & 10.35 \\
\hline M-II & 9.07 & 38.7 & 8.93 & 34.7 & 1.54 & 10.34 \\
\hline M-II & 9.07 & 38.9 & 8.92 & 35.5 & 1.70 & 8.74 \\
\hline
\end{tabular}




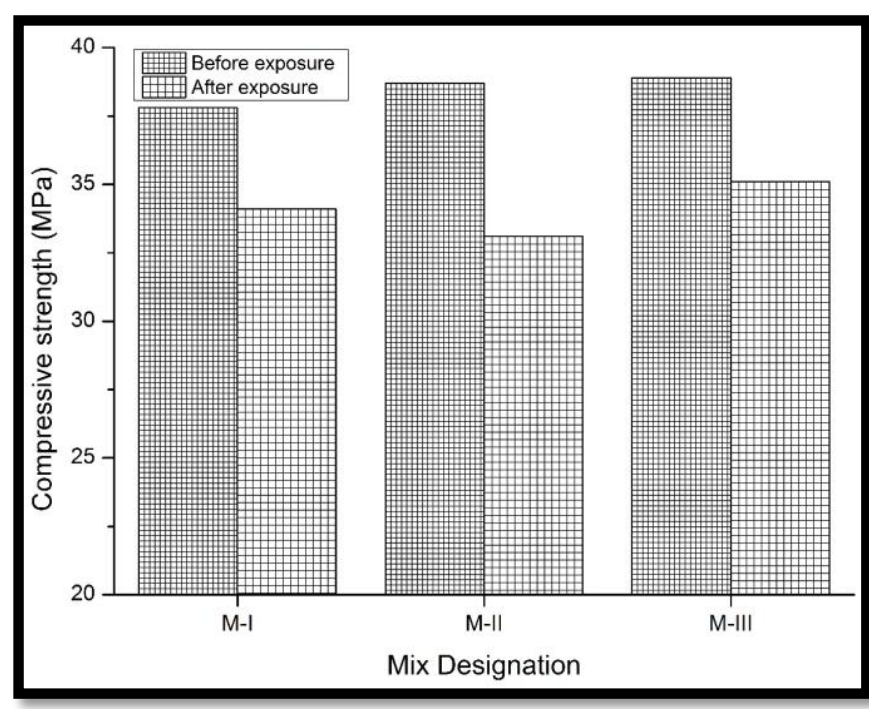

Figure 6. \% loss of strength for acid attack test

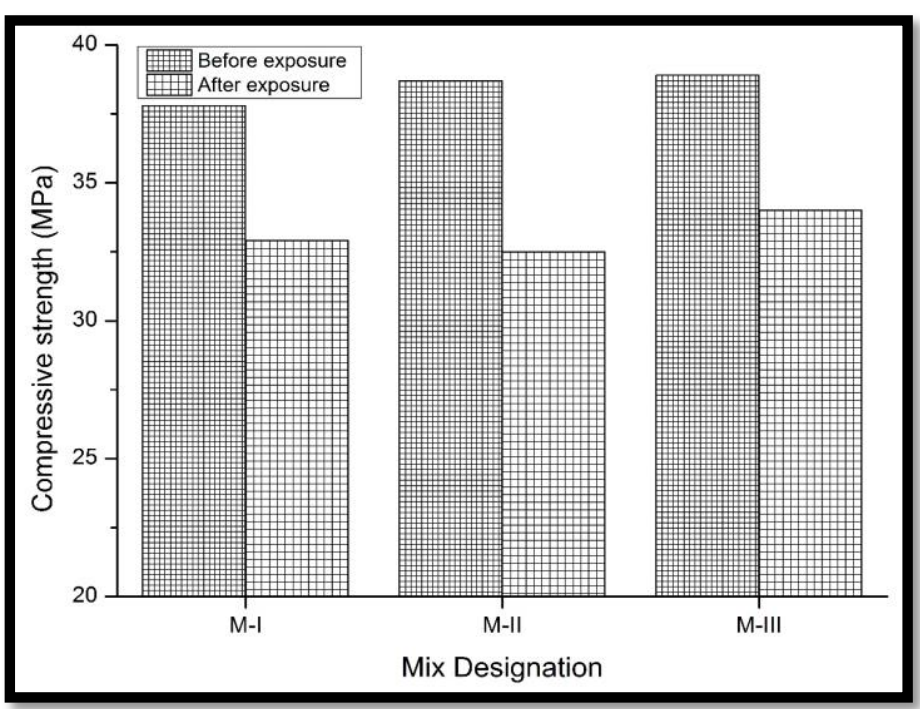

Figure 7. \% loss of strength for alkaline attack test

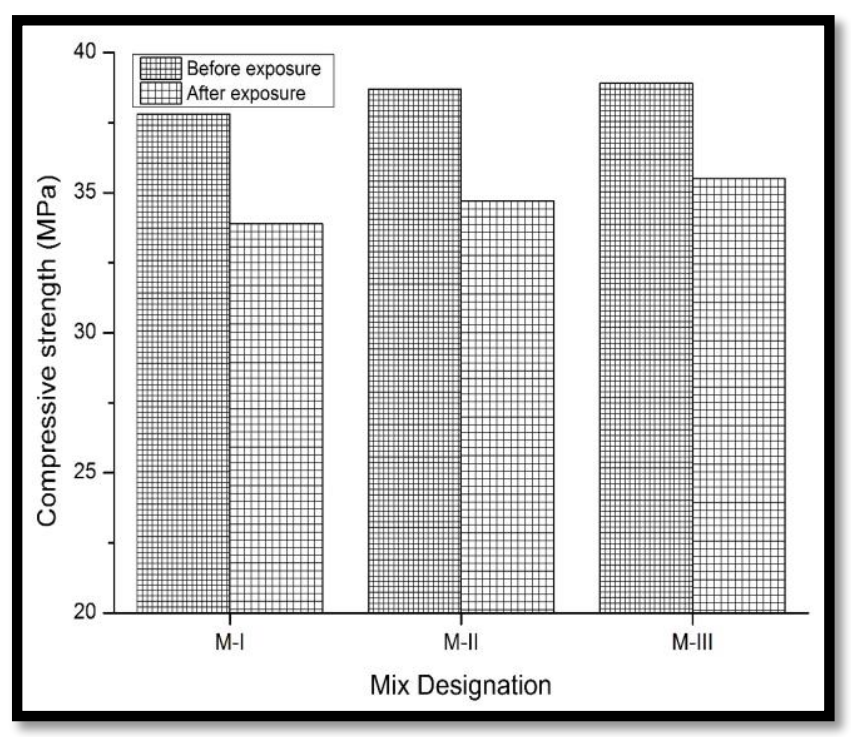

Figure 8. \% loss of strength for sulphate attack test

From the above Tables 5, 6 and 7 and Figures 6, 7 and 8 it can be seen that the $\%$ loss of mass and \% loss of strength for M-II is slightly higher when compared with M-I. However, in case of M-II, fly ash contribution can only be seen beyond 28 days of curing. Hence long-term studies are required to know about its sulphate resisting capacity. The studies conducted on GGBS mix(M-III) showed a reasonable performance when compared with other two mixes.

\section{RCPT TEST}

The RCPT kit was used to assess the resistance of concrete samples to chloride ion penetration. Cylinder specimens of $10 \mathrm{~cm}$ diameter x $20 \mathrm{~cm}$ height were cast and cured for 28 days. Concrete discs of 50mm thickness were obtained using circular diamond saw cutter. This concrete disc was mounted in between the two halves of the test cell. $3 \%$ sodium chloride solution was filled 
with one cell and attached to the negative terminal of the power supply. In the other cell 0.3 molar sodium hydroxide solution was filled and was attached to the positive terminal of the power supply. The test cells were sealed together with the help of sealant. The concrete discs were placed in RCPT test kit for a duration of six hours and a total of twelve reading with each reading been taken at 30 min interval. This reading obtained was in $\mathrm{mA}$. Figure 9 shows the RCPT Test under progress. Similarly, Figure 10 highlights the RCPT test results of concrete mixes at 28 days curing period. Charged passed through the samples is calculated as per ASTM $-\mathrm{C} 1202$

$\mathrm{Q}=900\left(\mathrm{I}_{0}+2 * \mathrm{I}_{30}+2 * \mathrm{I}_{60}+--------+2 * \mathrm{I}_{330}+\mathrm{I}_{360}\right)$

Where, $\mathrm{Q}$ is charge passed in coulombs,

$\mathrm{I}_{0}, \mathrm{I}_{30}, \mathrm{I}_{60}$. are current in amperes at $0,30,60 \ldots$ minutes respectively

Table 8 gives the typical readings of the RCPT test conducted on all the three samples at the age of 14 days. The values mentioned are the charge passed for every $30 \mathrm{~min}$ of $6 \mathrm{hrs}$ duration. Table 9 gives the chloride permeability based on the charge passed through the specimens.

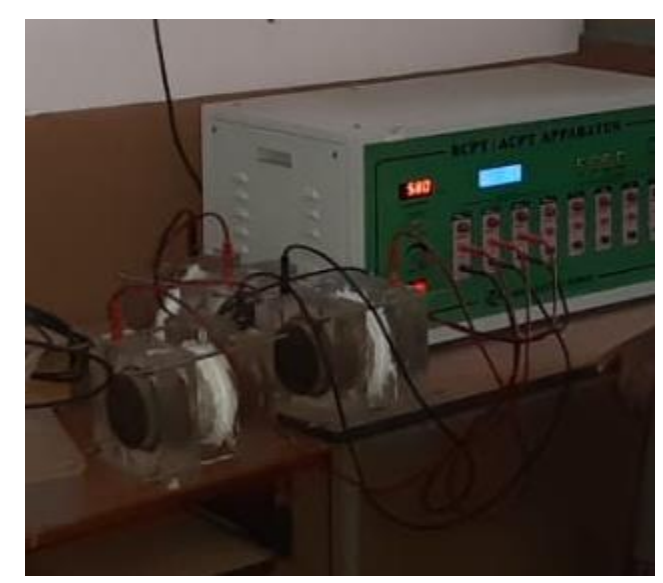

Figure 9. RCPT test specimen 
Table 8. RCPT test readings of the charge passed in $\mathrm{mA}$ for all the three samples

\begin{tabular}{|c|c|c|c|}
\hline \multirow{2}{*}{ Time } & \multicolumn{3}{|c|}{ Readings (mA) } \\
\cline { 2 - 4 } & M-I & M-II & M-III \\
\hline 10.51 & 0.236 & 0.155 & 0.096 \\
\hline $11: 21$ & 0.316 & 0.179 & 0.105 \\
\hline $11: 51$ & 0.354 & 0.193 & 0.11 \\
\hline $12: 21$ & 0.37 & 0.215 & 0.115 \\
\hline $12: 51$ & 0.398 & 0.231 & 0.119 \\
\hline $13: 21$ & 0.407 & 0.243 & 0.124 \\
\hline $13: 51$ & 0.411 & 0.25 & 0.129 \\
\hline $14: 21$ & 0.426 & 0.26 & 0.133 \\
\hline $14: 51$ & 0.431 & 0.263 & 0.147 \\
\hline $15: 21$ & 0.432 & 0.27 & 0.151 \\
\hline $15: 51$ & 0.437 & 0.273 & 0.153 \\
\hline $16: 21$ & 0.449 & 0.276 & 0.158 \\
\hline $16: 51$ & 8523.9 & 5116.5 & 2775.6 \\
\hline
\end{tabular}

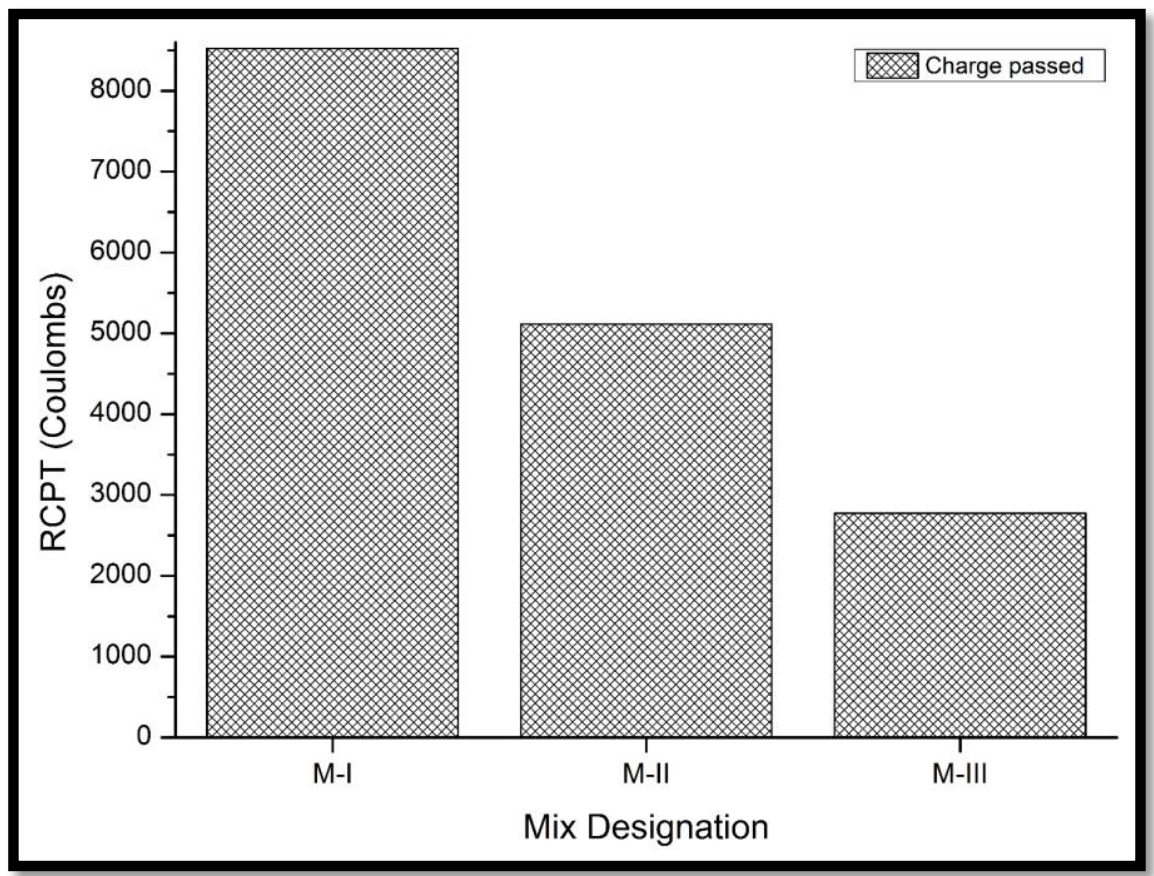

Figure 10. RCPT test results 
Table 9. Chloride permeability values based on the charge passed (coulombs).

\begin{tabular}{|c|c|c|}
\hline Mix Designation & Charge Passed & Chloride permeability \\
\hline M-I & $8523.9(>4000)$ & HIGH \\
\hline M-II & $5116.5(>4000)$ & HIGH \\
\hline M-III & $2775.6(2000-4000)$ & MODERATE \\
\hline
\end{tabular}

As specified in ASTM- C 1202, as the chloride permeability increases, durability decreases. From the Table 11, in case of Mix M-III, the chloride permeability is moderate and for the mixes M-I and M-II the permeability is high. Hence, it is evident that the mix comprising GGBS is more durable in comparison with the other two mixes i.e., Control mix and mix containing fly ash as part replacement of OPC.

\section{CONCLUSION}

Based on laboratory investigations and samples obtained from the ready-mix plant, compressive and split tensile strength tests, non-destructive tests, and durability tests were performed and compared to the other mixes, and the subsequent conclusions were drawn. All the mixes satisfy the strength requirements of M25 grade. Mix with fly ash is slightly lower strength when compared with the other two mixes. Based on the test results, it clearly indicates that the part replacement of cement with GGBS or fly ash does not alter the required strength using $100 \%$ of manufactured sand in place of river sand. Based on the NDT tests conducted, the quality of concrete obtained is good for all the mixes. The $\%$ of loss of mass and $\%$ of loss of strength for M-II is slightly higher when compared with M-I. However, in case of M-II, fly ash contribution can only be seen beyond 28 days of curing. The studies conducted on GGBS $\operatorname{mix}(\mathrm{M}-\mathrm{III})$ showed a reasonable performance when compared with other two mixes. From Chloride ion permeability test it is evident that mix with GGBS(M-III) showed better performance when compared with other two mixes i.e., M-I and M-II. Hence it can be recommended that for coastal regions use of GGBS is very beneficial and will increase the durability of the concrete. Results indicates that the use of $100 \%$ manufactured sand along with mineral admixtures in producing ready mix concrete is a good choice in view of the nonavailability of river sand to meet the demands of fast-track construction projects. 


\section{REFERENCES}

Ahmad, I., Shahzada, K., Ahmad, M. I., Khan, F., Badrashi, Y. I., Khan, S. W., Muhammad, N., \& Ahmad, H. 2019. Densification of concrete using barite as fine aggregate and its effect on concrete mechanical and radiation shielding properties. J. of Engineering Research 7:81-95.

Ali, S., Iqbal, S., Room, S., Ali, A., \& Rahman, Z. 2021. Value added usage of granular steel slag and milled glass in concrete production. J. of Engineering Research 9(1):55-67.

Alnahhal, M. F., Alengaram, U. J., Jumaat, M. Z., Abutaha, F., Alqedra, M. A., \& Nayaka, R. R. 2018. Assessment on engineering properties and $\mathrm{CO} 2$ emissions of recycled aggregate concrete incorporating waste products as supplements to Portland cement. J. of Cleaner Production, 203:822-835.

Anandan, S., Islam, S., \& Khan, R. A. 2019. Effect of steel fibre profile on the fracture characteristics of steel fibre reinforced concrete beams. J. of Engineering Research $7(2): 105-124$.

Güçlüer, K. 2021. An investigation of the effect of different aggregate types on concrete properties with thin section and nondestructive methods. J. of Engineering Research $9(3 \mathrm{~B}): 15-24$.

IS:383-1970. 1970. Indian Standard Specification for Coarse and Fine Aggregates From Natural Sources for Concrete. Bureau of Indian Standards. New Delhi. 1-24.

IS:12269-2013. 2013. Indian Standard Specifications for Ordinary Portland Cement, 53 grade specification. Bureau of Indian Standards, New Delhi. 1-10.

Lim, J. S., Cheah, C. B., \& Ramli, M. B. 2019. The setting behavior, mechanical properties and drying shrinkage of ternary blended concrete containing granite quarry dust and processed steel slag aggregate. Construction and Building Materials. 215:447-461.

Manjunatha M., Seth, D., KVGD, B., \& Chilukoti, S. 2021. Influence of PVC waste powder and silica fume on strength and microstructure properties of concrete: An experimental study. Case Studies in Construction Materials. 15:e0610.

Manjunatha, M., Vijaya Bhaskar Raju, K., \& Sivapullaiah, P. V. 2021. Effect of PVC Dust on the Performance of Cement Concrete-A Sustainable Approach. Lecture Notes in Civil Engineering 75:607-617.

Muthusamy, K., Rasid, M. H., Jokhio, G. A., Mokhtar Albshir Budiea, A., Hussin, M. W., \& Mirza, J. 2020. Coal bottom ash as sand replacement in concrete: A review. In Construction and Building Materials. 236:117507. 
Qureshi, L. A., Ali, B., \& Ali, A. 2020. Combined effects of supplementary cementitious materials (silica fume, GGBS, fly ash and rice husk ash) and steel fiber on the hardened properties of recycled aggregate concrete. Construction and Building Materials 236:120636.

Saluja, S., Goyal, S., \& Bhattacharjee, B. 2019. Strength properties of roller compacted concrete containing GGBS as partial replacement of cement. Journal of Engineering Research. 7(1):1-17.

Tangadagi, R. B., Manjunatha, M., Bharath, A., \& Preethi, S. 2020. Utilization of Steel Slag as an Eco-Friendly Material in Concrete for Construction. Journal of Green Engineering. 10(5):2408-2419.

Tangadagi Ranjitha, M. Manjunatha, Seth Dinesh, S. P. (2021). Role of mineral admixtures on strength and durability of high strength self compacting concrete: An experimental study. Materialia. 18:101144.

Thangapandi, K., Anuradha, R., Awoyera, P. O., Gobinath, R., Archana, N., Berlin, M., \& Oladimeji, O. B. 2020. Durability Phenomenon in Manufactured Sand Concrete: Effects of Zinc Oxide and Alcofine on Behaviour. Silicon. 15:1-7.

Xin, J., Zhang, G., Liu, Y., Wang, Z., \& Wu, Z. 2020. Numerical analysis of effect of temperature history and restraint degree on cracking behavior of early-age concrete. J. of Engineering Research. 8(2):24-43. 